Meta

Journal des traducteurs

Translators' Journal

\title{
A Training Program for Court Interpreters
}

\section{Jindra Repa}

Volume 26, numéro 4, décembre 1981

URI : https://id.erudit.org/iderudit/003938ar

DOI : https://doi.org/10.7202/003938ar

Aller au sommaire du numéro

Éditeur(s)

Les Presses de l'Université de Montréal

ISSN

0026-0452 (imprimé)

1492-1421 (numérique)

Découvrir la revue

Citer cet article

Repa, J. (1981). A Training Program for Court Interpreters. Meta, 26(4), 394-396. https://doi.org/10.7202/003938ar d'utilisation que vous pouvez consulter en ligne.

https://apropos.erudit.org/fr/usagers/politique-dutilisation/ 
BLOC-NOTES

\section{A TRAINING PROGRAM FOR COURT INTERPRETERS}

I would like to share with the readers of Meta our experiences with a training program for court interpreters in British Columbia. I hope to provide you with a few thoughts on a subject which has traditionally been neglected by both interpreters and the legal profession. Court interpreting, however, is an integral part of daily court routine in Canada and requires the same attention and development as some of the more commonly thought of aspects of interpreting.

Court Interpreting in Canada appears to be a rather unstructured activity and as a profession it is probably in its infancy. I would like to present here an outline of a training program for court interpreters and my references to court interpreting as an activity or profession will be restricted to factors directly involving the training program. Other studies and reports, dealing with legal and organizational aspects of court interpreting, are underway ${ }^{1}$.

Vancouver Community College, Langara Campus, Continuing Education, offered the Program in Court Interpreting for the first time in the fall of 1979. The first class of court interpreters graduated from this two term, part-time study training program in June, 1980. The second class of court interpreters commenced their training in the fall of 1980.

\section{Development}

A group of Vancouver court interpreters became aware in 1978 of the need for a training program for court interpreters. Consider the following circumstances: At the time, no system of accreditation of court interpreters existed in British Columbia, no proof of language proficiency was required from an interpreter before

1. Kathleen Keating, "The role of the interpreter in the trial process', unpublished.

Roda Roberts, ed., (1980): «L'Interprétation auprès des tribunaux », Cahiers de Traductologie $\mathrm{N}^{\circ} 3$, Ottawa, Éditions de l'Université d'Ottawa. he or she was admitted to the court, the duties of court interpreters were nowhere specified and persons requiring interpretation in the courts had often conflicting, or vague views as to, not only, what an interpreter should interpret, but also how he or she should do so. The introduction of a training program for court interpreters was intended as a first step toward an improvement of the court interpreting services in British Columbia.

A group of court interpreter curriculumdevelopers consulted a large number of professionals directly involved in court interpretation (members of the judiciary, court interpreters, administrators). It rapidly became apparent that the proposed program was receiving adequate support from parties in daily contact with court interpreters, and that many counsels and interpreters felt that such a program was, in the words of one speaker, "long overdue".

\section{Curriculum}

The general approach used in the preparation of the program curriculum was pragmatic and was determined by locally perceived needs rather than by a particular set of theories of language or jurisprudence. Research into the structure of related programs revealed a similarity between the components of our curriculum and the curriculum of the only other Canadian program in Court Interpreting: Certificate Program in Legal Interpretation, School of Translators and Interpreters, Laurentian University, Sudbury. Instruction in the program covered the following three areas: interpretation, legal education and communication. Each component provided a blend of theoretical and practical training. Approximately 180 hours of instruction were completed over the period of two terms and complemented by a practicum period. The following is a course list with time allocations :

1. History and Philosophy of the -15 hours B.C. Legal System 
(An introduction to the principles of law)

2. Communications

(Listening skills, an awareness of the complexity of the communication process, note taking, memory retention skills, nonverbal communication, public speaking)

3. Terminologies and Procedures (System description, terminologies seminar)

4. Interpreting

(Interpretation coaching in groups by languages of specialty, use of trial transcript)

5. Court Role Playing

(Simulated court situations, practice interpretation)

6. Interpreting Workshop (Court Interpreter Seminar)

7. Video Self-Evaluation Workshop

(Practice of all interpreting skills in front of a camera)

8. Business Aspect of Court Interpreting

(Aspects of freelance work, skills marketing)

9. Law Library Orientation (Overview, reference exercises)

10. Individualized Programs (Pronunciation)

The first three courses were offered during the Fall Term - 1979, courses 5-10 were offered in the Spring Term - 1980 and the interpreting course was offered throughout the whole academic year.

A student practicum provided an opportunity for the students to interpret in the courts and within the community. This was made possible due to the co-operation between the College and the provincial Ministry of the Attorney-General As no system of accreditation of court interpreters presently exists in British Columbia, the student interpreters were eligible to act as paid court interpreters at the time of the practicum. As Court Interpreting develops in British Columbia, and standards for admission of court interpreters to the courts are established, we anticipate a change in the format of our student practicum.

\section{Languages of Specialty}

An impressive number of languages is used for court interpretation purposes in British Columbia. We felt that any restriction with respect to the admissible languages of specialty would limit the effectiveness of the program vis- a-vis the actualities. In principle, language resource persons and instructors were employed as needed to provide support for students who were selected exclusively on the basis of the results of a language proficiency examination.

Ten languages of specialty were represented among the applicants to the program. This number was reduced during the selection process to seven languages of actual representation in the class: French (8), Cantonese (4), Hindi (1), Portuguese (1), Punjabi (1), sign language (1), Spanish (1).

Several languages of specialty required for interpretation in the courts of British Columbia were represented only marginally or not at all among the applicants: Greek, Italian, Vietnamese, for example. Our experiences with student selection for the 1980-1981 class indicated the possibility of building up over the period of several years a truly representative pool of specialists in virtually all languages required for interpretation in the courts of this province.

(The 1980/1981 class of court interpreters is composed of 6 specialists in Spanish, 5 in French, 3 in German, 3 in Mandarin, 2 in Cantonese and 1 in Punjabi.)

\section{Language Proficiency}

The program developers required a thorough knowledge of written and spoken English and one other language as a pre-requisite for admission to the program. Resultantly, the program was not designed to improve the students' proficiency in either language. Successful completion of a rigorous language proficiency examination was, and continues to be, a pre-requisite for admission to the program.

Many applicants for admission were uncertain or mistaken about their language proficiency. The level of proficiency required fo interpreting in the courts is higher than some applicants expected. Only 24 persons out of 55 applicants were successful in the language proficiency examinations held in 1979. Undoubtedly, a subjectively perceived level of proficiency may often differ from its independ. ent evaluation. It further appears that many applicants had not had an opportunity to have their language proficiency evaluated prior to taking our entrance examination. Others believed that academic degrees earned in specific languages indicated a level of proficiency sufficient for the purposes of court interpreting

\section{Entrance Examinations}

The entrance language-proficiency examinations consisted of four parts :

1. Oral interpretation of spoken statements from English to-a language of specialty.

2. Oral interpretation of statements from a language of specialty to English. 
3. Written translation of a text from English to a language of specialty.

4. Written translation of a text from a language of specialty to English.

Each part was approximately 250 words long. Each part was evaluated on a pass/fail basis (acceptable/unacceptable). The acceptable level of proficiency has been determined by each examiner by following the directions and principles outlined above. Consultations and second opinions were provided where necessary and when requested.

It was felt that this particular examination method requiring the applicant to translate and interpret was suitable not only for the purposes of determining safely the applicant's proficiency but also offered an additional opportunity to evaluate the applicant's aptitude for the rendering of messages from one language to another.

Faculty

The program's curriculum called for the co-operation of two professions: lawyers and interpreters, with the additional support and participation of communication specialists. Language resource persons, either interpreters or language teachers, were employed to provide support in each language of specialty.

\section{Future Developments}

The introduction of our Program was intended as a first step towards the much-needed development of Court Interpreting Services in British Columbia. I feel that the following factors will also be important for further developments: The role of the recently-formed British Columbia Society of Translators and Interpreters in the field of Court Interpretation; and co-operation between the provincial Ministry of the Attorney-General and our training institution with regard to examination and admission of interpreters to the court.

With respect to the Program's format and curriculum, decisions will have to be made regarding a more permanent structure. Questions such as whether one year of part-time study and 180 hours of instruction are sufficient will need to be answered, as well as whether consideration should be given to a broader theoretical approach to the training of court interpreters. 